發調査㕑』の一行と共飞渡道し，北海道濶葉樹がパルプ資源として 重大な意義を有する事を贸地に見聞し，北海道廳の御好意儿依り奇 䁚を受けを試料に就き研究を行つたるのである。試料提供に關し
て種々盡力を賜つた北海道北見營林區署に、對し茹に謝意を表する 次第である。また濶葉樹の腐朾の問題に關し種々御示教を賜つた 京都帝國大學教授逸見武雄博士に對し梁甚の謝意を表する。

\title{
(173) 精油中のテルペンアルコールの簡易定量法
}

\section{河 內 二 郎}

精油中のテルヘンンアルコールの定量法として普通一般に用ひら るらは醋化法なり。又特殊の方法として脫水量定量法, 硼酸法, 又 Grignard 試藥によりメタンガスを發生せじめて定量する Zerewittinoff ${ }^{1)}$ 法等あり。この中醋化法は最も普通に用ひらる るも、アルデヒドの共存する試料にありてはアルデヒドの轉位に より二次的のアルュールを生じ, 兩者共醋化さる」結果; 兩者の 和として現はるうものにしてシトロネラ油中のゲラニオール，シ トロネラールはその好適例なり。

著者はシトロネラ油の分析法を研究し來りしが;一般に用ひら

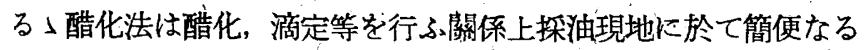
方法として行ひ難し。著者は之に代るべき正確にして而も簡便な る方法を求めんとして偶々サリチル酸ソーダ溶液がテルペンアル コール類を溶解する性質あるを知り，これを利用して行ひ得ざる かを實驗し，先つ精油各成分のサりチル酸ソーダ溶液に對する溶 解力を測定したるを以て，その結果並に定量法としての實驗を他 の定量法と比較し行ひたる結果に就き報告するものなり。

試藥として使用するサリチル酸ソーダはサ、チル酸 1 モルに對

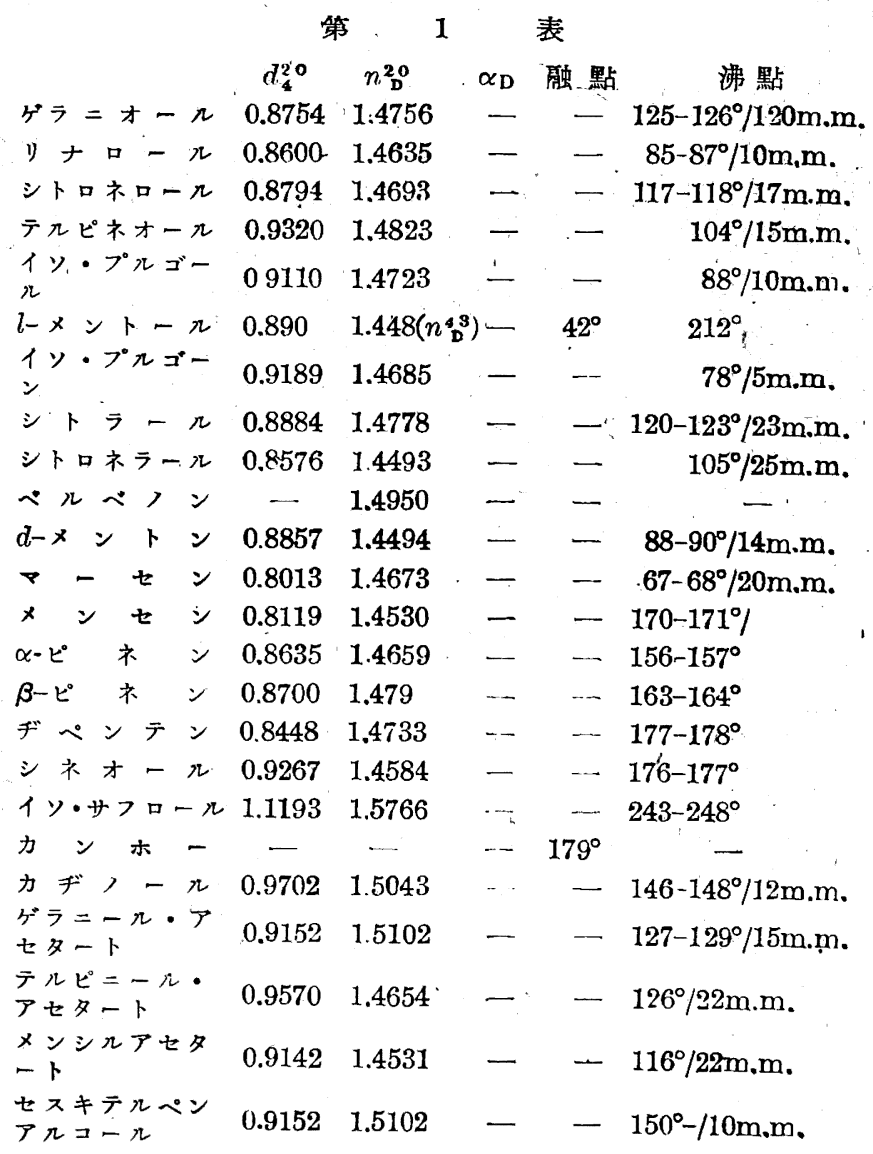

し重炭酸ソーダ1モルより得らる。サリチル酸ソーダは1.2 分子の 結晶水を有する微粒狀晶にして少量の不純物を含むも結晶せず。 日光及び濕氣により作用され變質するを以て貯藏に注意を要す。 常溫 $\left(20^{\circ} \mathrm{C}\right)$ に於て飽和溶液は $56 \%$ なり。尚定量に使用後の試 藥は水にて稀釋し, 油分を分離後稀鑛酸にて中和してサッチル酸 を包收し得（包收率 98\%)。又用るし試料は常法により精製し第 I 表の如き恒數を示すりのなり。

溶解度測定は試料 1ec（固體は1g)をとり）これにサリチル 酸ソーが各種濃度溶液を徐々に加一水浴上に温め放冷後完全に溶 解せしむるに要する試薬の添加 $r c$ 數を以て示したり。

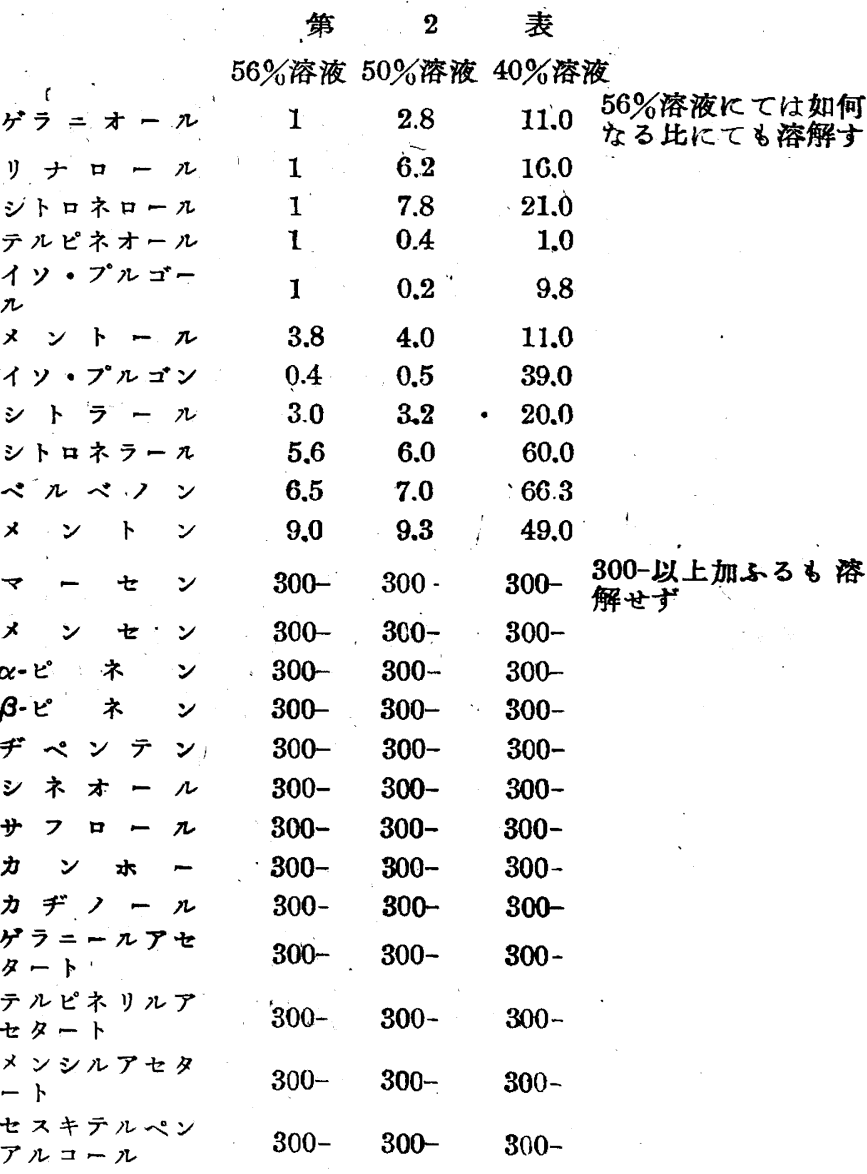

以上を試料別に見るにアルコール類，アルデヒド類，樟腦を除 くヶトン類は溶解度大なるもェーテル類, 炭化水素類, セスキテ ルンン類にありては 300 倍以上加ふるも溶解せざることを認めた b。

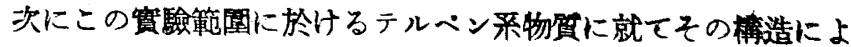
る溶解度の差を检するに，第 1 級アルュールは概して第 3 級 ル 


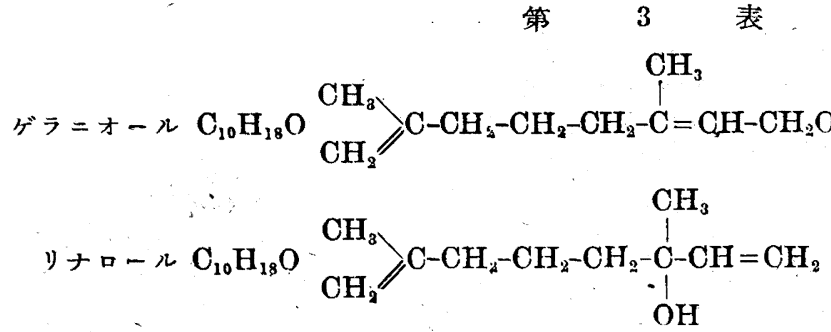

$$
\begin{aligned}
& \text { 第 } 4 \text { 表 } \\
& \text { テルピネォール } \mathrm{C}_{10} \mathrm{H}_{18} \mathrm{O} \quad \mathrm{CH}_{3}-\mathrm{C} / \mathrm{CH}_{\mathrm{CH}_{2}-\mathrm{CH}_{2}}^{\mathrm{CH}-\mathrm{CH}_{2}}>\mathrm{CH}-\mathrm{C}_{\mathrm{CH}_{3}}^{\mathrm{OH}} / \mathrm{CH}_{3}
\end{aligned}
$$

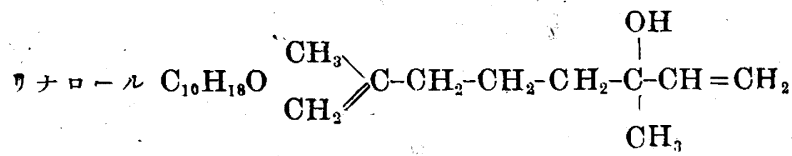

$\begin{array}{cc}50 \% \text { 溶液 } & 40 \% \text { 溶液 } \\ 2.8 & 11.0 \\ & \\ 6.8 & 16.0\end{array}$

$50 \%$ 溶液 $\quad 40 \%$ 溶液

1.0

16.0
解度差大なる溶夜にして大量 の試燕を使用せざる籁圍とし て 40\% サリチル酸溶液を使 用し，之によりてアルコール のみの定量に利用せんとし， 凡18倍量を限度とし次の如き 操作を行ひたり。1/10cc 目盛 を施せる內容 50cc の細徑力 シヤフラスコに檢油 $2 \mathrm{cr}$. を 取り，これに試藥 18 倍量郎ち $36 \mathrm{cc}$ 2 3 可に分ちて加一 充分に振逿し約 $5 \sim 10$ 分間 水浴上に溫め, 後同溶液にて 目盛まで静置放冷後上層に济 ぶ殘油量を目瀷にて次式によ らて計算す。

アルュール\%=(檢油の cc 數一殘油の $\mathrm{cc}$ 數 $) \times 100 /$ 檢

油の cc 數

試料として天然のシトロネラ油, 薄荷油, 檜油, 芳樟油を模做 して同樣なる成分を有する人造精油を調合作製せんとし第 1 表人 使用せる試料を使用して次の如く調合せり。

調合シトロネラ油，ら゙ラニオール，37.2\%，シトロネラール，

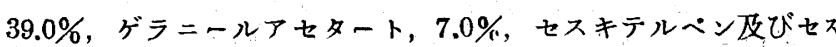
キテルペンアルコール, $12.9 \%, \alpha$-ピネン $0.5 \%$, ヂヘンテン $2.4 \%$ 。

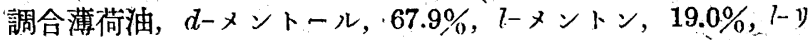
モネン, $7.4 \%, p$ メメンン, $2.0 \%$ 。

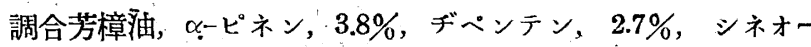
ル，18.0\%，リナロール， $50.0 \%$ ，樟腦, $11.0 \%$,テルピネオール， $2.5 \%$ ，セスキテルベン及びセスキテルペンアルコール，12.0\%。

調合檜㹨, $\alpha$-ピネン; $27.4 \%$ ，ヂペンテン， $24.4 \%$,テルビネオ ール， $14.2 \%$ ，テルピニールアセタート, $2.0 \%$ ，七スキテルペン $160 \%$ ，セスキテルペンアルコール，16.0\%。

1. 炭化水素に屬する總てのテルンンン類は難溶なり。

2.モノテルベンの中, 鎖狀, 單環狀を問はずアルュール類は よく溶け，ヶトン，マルデヒド類も一般に溶解度大なり。

3. 双環性のものはべルベノンの如く溶解寸るすのあるもシネ オール，サフロール，樟腦の如く概して難溶なり。

4. エーテル類及びェステル類は難溶なり。

5. セスキテルペン類はアルュールと雖も難溶なり。

これ等の事實よりして，或精油の成分を知ればその內容により サリチル酸ソーダ溶液に對する溶解度を利用して容易に目的成分 の定量をなし得べきか否かを決定し得ることは，恰も從來の分析 法に於ける精油に對する適不適を知る場合々同樣なるべき筈な り。又その成分の構成に從てサッチル酸ソーダ溶液の使用すべき 濃度を適當に選定することによりて目的を達し得べきことも明か なるべし。

この推定か實際的に果して適合するや否や，又成分個々につき ては上述の溶解度を示すり, 泳合せる場合に同粶なる結果を示す や否やを知るを要す。これが瓷に既知テルべン類を使用して天然 精油に近き成分を有する試料を作り，これを他の定量法と本行し て分析し，著者の方法の正確度を檢せり。一般的方法として第 1

\begin{tabular}{|c|c|c|c|c|c|}
\hline \multirow{3}{*}{ 調合ジロ } & \multirow{2}{*}{\multicolumn{2}{|c|}{ 含有アルコール\% }} & \multirow{2}{*}{$\begin{array}{r}\text { 裴 } \\
\text { 本法 }\end{array}$} & \multirow{2}{*}{ 從來の方法 } & \multirow[b]{2}{*}{ 摘要 } \\
\hline & & & & & \\
\hline & $\begin{array}{l}\text { ゲラニオール } \\
\text { シトロネラール }\end{array}$ & $\begin{array}{l}37.2 \\
39.0\end{array}$ & $37.4 \%$ & $\begin{array}{r}7 \\
\text { (全) }\end{array}$ & 醋 \\
\hline 調合薄荷油 & メントール & 67.9 & $\begin{array}{l}67.0^{\circ} \\
(52.09\end{array}$ & $71.06 \%$ & 醋代 \\
\hline 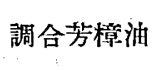 & $\begin{array}{l}\text { テルピネオール } \\
\text { リナロール }\end{array}$ & $\begin{array}{r}2.5 \\
50.0\end{array}$ & $52.0 \%$ & $51.6 \%$ & $\begin{array}{l}\text { 胫水量 } \\
\text { 法(3) }^{(3)}\end{array}$ \\
\hline 胃全 & $\begin{array}{l}\text { テルピネオール } \\
\text { セスキテヘヘン } \\
\text { アルコール }\end{array}$ & $\begin{array}{l}14.2 \\
16.0\end{array}$ & $14.5 \%$ & $27.06 \%$ & \\
\hline
\end{tabular}
表の結果を考虑し，アルコール及びアルデヒド，ヶトン類との溶
以上の結果より見れば效字に現れたる如く，一般によく調合に 用ひたる成分數字と一致せり。アルデヒド及びヶトンを共存寸る 精油にありては幾分正確度低き觀あれども，之を從來の定量法と 比較するに寧ろ優秀なる成績を示せり。殊に芳樟油，檜油の定量 の結果䋫著なるは第 1 表の如くセスキテルベンアルュール類, 樟 授等の存在は何等影響を與へざることを示すりのなり。表中薄街 油に於ける*印は特別に $50 \%$ 溶液にて定量せるめのにして40\% 溶夜にては結果良好ならず。これは既にメントンの分離特詳（第 89246 號 $)^{21}$ にも記載せらる」が如くサリチ儿酸溶液の量, 浱度 及び溫度によりメントンの溶解度はメントールより大となり， 
結果として共にサリチル酸に溶解す。故に $50 \%$ 溶液を 20 倍量

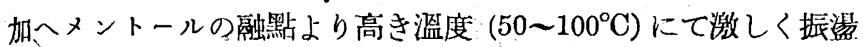
して行ふ時は好結果を得。シトロネラ油に於ては，アルデヒド共 存すれども注意して行ひ、そのま」にて比較的好結果を得たり。 一般にアルデヒド及びヶトンの共存するものにありては，その含 有アルコール量により, 或はその試藥の添加量を幾分考慮する要 あるべし。郎ち此際サリチル酸ソーダ溶液の濃度並に检油に對寸 る添加量及び溫度等が重大なる因子をなすが煘なり。又これらの 條件も含有成分によりて變化あるを以て, 成分未知の檢油に就て 直ちに本法を通用することの無謀なるはいふ老俟たず。

何れにせよ上述の如く混合物乃至天然精油模造品により, 既知 アルコール含有量は本法により雔想以上の好結果を以て定量し得 るを知りたるを以て，之を更に實際の天然精涌に試み，倘從來の 定量法に小る結果を作也記したるもの第 7 表の如し。薄街油は 5 0\% 溶液，其他休 40\% 溶液を用ひたること前述せるが如し。こ わ結果の正しかるべきことは第 6 表の賽驗によりて明かなるもの なれど，之を從來の夫々の精油に適すと考へられたる定量法と比 較するによく一致せりといふべし。之によりて見れば成分既知の 精油にして從來のアルコール定量法によるものは何れも本法によ り充分に定量し得ることを認めたり。加之樟腦油, 芳油; 檜油に ありては一般に既知の方法にては定量困難なりとせられたるが， 本法によれば容易に定量し得られ，シトロネラ油及び薄荷油にあ りても注意して行はば既知の方法と”等しき數字を示すものなり。 かくてサリチル酸りーダ法は容易, 正確なる一新定量法として 使用し得べしと信ず。特にその特徵として考へらる」點を擧ぐれ ば次の如し。

1. 器具, 試劑, 方法, 何れも簡單にして隨時隨所に行ひ得べ Lo

\begin{tabular}{|c|c|c|c|c|}
\hline & $\begin{array}{c}\text { 第 } 7 \text { 表 } \\
\text { 含有アルコール }\end{array}$ & 然 & $\begin{array}{l}\text { 油 } \\
\text { 從来の方法 }\end{array}$ & 摘 要 \\
\hline $\begin{array}{l}\text { シトロネラ油 } \\
\text { 〔跮激」. }\end{array}$ & $\begin{array}{l}\text { ゲラニオール } \\
\text { シトロネラール }\end{array}$ & $40 \%$ & 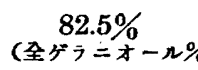 & \%) 醋 化 法 \\
\hline 薄荷油 [內地] & メントール & $72.6 \%$ & $73.0 \%$ & 醌 化 法 \\
\hline 薄荷油[內地] & メントール & $70.6 \%$ & $70.0 \%$ & 醋化法 \\
\hline 薄荷油 [队地] & メントール & $61.9 \%$ & $62.0 \%$ & 醋 化 法 \\
\hline 椲腦芳油[支那] & リリナール & $45.0 \%$ & $45.6 \%$ & 脫水量法(3) \\
\hline 牛樟油[臺游] & テルピネノール・4 & $50.0 \%$ & $50.0 \%$ & 分 \\
\hline 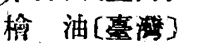 & テルピネオール & $30.0 \%$ & $29.8 \%$ & 分 \\
\hline
\end{tabular}

2. アルデヒド類の混在せる゙精油に適用して從來の醋化法の缺 點を除き得。

3. セスキテルペンアルコールの如きもの小混在せる精油に適 用して，テルベンアルュールのみを分離定量し得。

4. 分溜の如き不完全なる方法以外に定量する途なきが如き精 油に適用して正確なる定量をなし得。

$$
\text { 女。譬 }
$$

1）樟腦技術者協議會制定「樟腦；樟腦油並に副座油分析法」 p. 19 , 昭和 15 年

2）特許第 89246 號，小野嘉七，木村清三; 小野嘉七著1 天然 薄荷及合成薄荷」 p. 90 , 昭和 14 年

3）樟腦技術協議會制定「樟腦, 樟腦油並に副產油分析法」 p. 229, 昭和 15 年

本研劣に關し終始御懇篤なる御指導御鞭撻を賜りし高砂化學工 業株式會社專弨取締役, 理學博士堀內利器氏, 技術部長, 理學博士 本泉貞吉氏並に種々御捘助下されし研究室主任沼井䧼太郎氏に深 謝し，併せて發表を評可せられし同证に對し感謝の意を表す。 